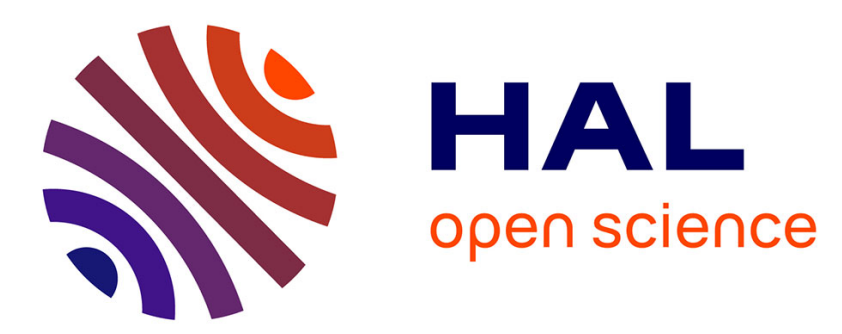

\title{
Making darkness a place-based resource: how the fight against light pollution reconfigures rural areas in France \\ Dany Lapostolle, Samuel Challéat
}

\section{To cite this version:}

Dany Lapostolle, Samuel Challéat. Making darkness a place-based resource: how the fight against light pollution reconfigures rural areas in France. Annals of the Association of American Geographers, 2020, pp.196-215. 10.1080/24694452.2020.1747972 . hal-02612864

\section{HAL Id: hal-02612864 \\ https://hal.science/hal-02612864}

Submitted on 26 Jul 2021

HAL is a multi-disciplinary open access archive for the deposit and dissemination of scientific research documents, whether they are published or not. The documents may come from teaching and research institutions in France or abroad, or from public or private research centers.
L'archive ouverte pluridisciplinaire HAL, est destinée au dépôt et à la diffusion de documents scientifiques de niveau recherche, publiés ou non, émanant des établissements d'enseignement et de recherche français ou étrangers, des laboratoires publics ou privés. 


\title{
Making darkness a place-based resource How the fight against light pollution reconfigures rural areas in France
}

Dany Lapostolle, Samuel Challéat

\begin{abstract}
Light pollution refers to the degradation of darkness through the use of artificial light at night (ALAN) in and around human infrastructures. This pollution is intrinsically related to urbanization and spills out from urban areas to affect both rural and protected areas. Several countries are organizing the fight against light pollution. There, local communities are experimenting with environmental policies designed to protect darkness. The challenge is about preserving biodiversity and fostering the energy transition. In France, a number of pioneering rural areas are experimenting with mechanisms that include this dual implication. Two of them provide the case study for this article. We show how these areas turn darkness into a specific resource. We identify three specification processes. The first obeys an anthropocentric utilitarian rationale and is part of the "economicization" of the environment in the line of shallow ecology. The second follows a rationale of ecocentric conservation and is part of the radical ecologization of the economy, in line with deep ecology. The third is in keeping with an integrated socio-ecosystemic rationale enshrining the interdependence between development, planning, the preservation of biodiversity, and energy savings. Local areas are plagued with specification controversies. These areas become incubation rooms, that is, spaces for resolving these controversies. These are reflected in a transition operator enabling the local area to take a fresh trajectory in terms of development and planning.
\end{abstract}

Keywords. Artificial light at night (ALAN); Darkness; Light pollution; Resource specification; Transition pathway 


\section{Introduction}

In its 2020 strategy for smart, sustainable and inclusive growth ${ }^{1}$, the European Union (EU) has defined its "Roadmap to a Resource Efficient Europe" 2 ". Rural areas play a key part in this multiscale strategy for restoring biodiversity and promoting the low-carbon transition. They take up new environmental concerns including in particular the protection of darkness.

Light pollution refers to the deterioration of darkness by artificial light at night (ALAN), in and on approaches to human infrastructures. Such pollution, which is related to urbanization, soared in the second half of the $20^{\text {th }}$ century by as much as $20 \%$ per year, depending on the geographical area in question (Hölker et al., 2010). More recently, between 2012 and 2016, it is estimated to have grown worldwide by $2.2 \%$ per year in area; and by $1.8 \%$ per year in radiance (Kyba et al., 2017). Through dispersion by aerosols suspended in the atmosphere, ALAN strays far beyond urbanized areas and impacts a non-negligible proportion of surrounding ecosystems (Kyba et al., 2013) in rural areas and in protected zones (McDonald, 2009). ALAN is therefore a particularly relevant marker of the artificialization of environments (Azam et al., 2016) and of expanding global environmental change.

ALAN has become a major subject of concern because of its multiple costs to biodiversity and the working of ecosystems (Gaston, 2013) as well as to human health and well-being (Stevens \& Zhu, 2015). Ecological studies report that light sources trigger mechanisms of attraction and repulsion locally; on larger scales, it disorients some species as they move around or migrate. ALAN is also a source of spaces pockmarking and fragmentation: some animals cannot get across illuminated structures (Laforge et al., 2019). It reportedly disturbs some animals' behaviours (communication, reproduction, predation...) and has negative effects on plant life: perturbed growth and flowering periods, troubled reproduction through effects on pollinating insects... (Knop et al., 2017).

In socio-cultural terms, the loss of natural darkness deteriorates a number of scientific (Riegel, 1973) and cultural amenities (Gallaway, 2010; Stone, 2017; Challéat \& Poméon, 2019). ALAN "closes the window" on the starry sky (Isobe et al., 1998) and rarefies opportunities for direct contact with a naturally dark environment. In this, ALAN contributes to depriving people of enjoying experience of nature (Pyle 1978; Miller 2005; Soga \& Gaston, 2016) thereby fuelling a generational environmental amnesia (Kahn, 2002).

The analysis of nocturnal time in town planning and urban development studies (Gwiazdzinski, 2009; Shaw, 2015; Mallet, 2009) highlights the concept of "chronotopia" to show how urban projects incorporate patterns of variation in the uses of places. This urbanistic concept is akin to the geographical concept of "nocturnal territoriality" (Raffestin, 1988), which underscores the role of night-time darkness regarding the change in our daily relations with the places we experience. To know nocturnal territorialities is to know in a situated way the daily practices and uses in and of the night-time (Challéat \& Lapostolle, 2018). This knowledge enables us to move towards the "right lighting", a new urban lighting doctrine that seeks a settlement between our needs for artificial light and the set of needs for darkness - be they ecological, health-based and/or sociocultural (Challéat, 2019). Cultural geography studies emphasize the extent to which darkness allows original forms of conviviality and intimacy, occupation of public spaces and perception of

\footnotetext{
$1_{\text {http://eur-lex.europa.eu/legal-content/EN/TXT/PDF/?uri=CELEX:52010DC2020\&from=EN }}$

$2_{\text {http://eur-lex.europa.eu/legal-content/EN/TXT/PDF/?uri=CELEX:52011DC0571\&from=EN }}$
} 
the world through senses other than sight (Edensor, 2013, 2015; Shaw, 2018). In other words and whatever the types of space in question, the darkness preservation provides access again to an array of experiences for the sensorial apprehension of the world.

Through the reduction of ALAN that it requires, preserving darkness also has implications for the energy transition. Worldwide urban lighting accounts for $19 \%$ of energy consumption with 4 billion public outside lights currently in use. In Europe there are 90 million urban lighting lamps in service, $75 \%$ of which are more than 25 years old, and they still include 20 million high-pressure mercury light sources. Urban lighting therefore seems to have been struck by obsolescence. In Europe, the renewal of light sources for enhanced energy efficiency is regulated by the Energy related Products Directive and the revised road lighting standard EN 13201. LED technology is at the heart of debate because of the risk of a rebound effect. For example, lighting in the UK has doubled in efficiency in the last 50 years. But over the same period, electricity consumption per inhabitant for lighting has quadrupled (Fouquet \& Pearson, 2006). However, different flexible technologies are emerging: variable intensity lighting, differentiated management systems in space and time for groups of lights, or the adaptation of light intensity to different human and non-human uses of night-time space (Zissis \& Kitsinelis, 2009). These may contribute to a socio-technical solution for area development to preserve and restore biodiversity while limiting the rebound effect. Some rural areas are adopting them and serving as testing grounds for constructing their sustainable development strategy around the preservation of darkness.

It is the aim of this paper to show how, through the emergence of darkness as a resource, both the restoration of biodiversity and the energy transition have become guiding principles for regional development. In France, Europe 2020: A Strategy for Smart, Sustainable and Inclusive Growth takes the form of institutional changes initiated by the Grenelle Environnement (governmentsponsored roundtable talks on the environment), followed by legislation on the energy transition for green growth (2015), new regional organization (2015), and the reclaiming of biodiversity, nature and landscapes (2016). This legislative package determines the conditions for taking into account the energy transition and the restoration of biodiversity in land-use planning. This way, all ordinary or protected rural areas are made part of multi-scale mechanisms meant to map out a pathway for an energy transition and the restoration of biodiversity. In terms of reducing ALAN, the Association nationale pour la protection du ciel et de l'environnement nocturnes (ANPCEN, or National association for the night sky and the nocturnal environment protection) reports that some 12,000 , mostly rural or outer suburban, councils, are reducing their outside lighting. But it is primarily economic pressure that comes to bear, since outside lighting is one of the more expensive items in rural councils' budgets. The environment is less of a concern. However, a few pioneering councils are attempting to promote darkness as a resource. It is on these that we shall concentrate: they are incubation zones, intended to spread their experimental approaches to other areas, in other words, for turning the transition into the norm for development and planning.

Our line of argument runs as follows: by making darkness a resource for sustainable development and planning, these rural areas have become part of the fight against global environmental change. It is from the controversy between two schematic concepts of darkness - one related to the economicization of ecology and the other to the ecologization of the economy - that an actor network emerges. This actor network creates the conditions for a territorial reflexivity that is able to redefine development trajectories around the specification of darkness as a resource in two ways: by organizing the movement of socio-cultural references on multiple scales and deliberation about the values attributed to darkness, and by promoting change in representations of the night. This 
aptitude is materialized by the creation of a place-based transition operator - sometimes the Trame noire, sometimes the nocturnal landscape — that reconfigures the development pathways of these rural areas. It is in this spatial re-patterning and by spreading the process to other rural areas that these pioneering areas become incubators, i.e. spaces of innovation for concerns relating to new forms of environmental resources.

\section{Conceptual framework}

By putting the fight against light pollution and the preservation of darkness (Challéat \& Lapostolle, 2014) on the agenda, a number of rural areas take part in the global countryside (Woods, 2007). Indeed, they imply interactions between local and world actors, between human and non-human actants, and the circulation of reference standards and good practices so as to bring about a reconfiguration of regional development and planning policies. This is the visible part of including rural areas in the global countryside, but a finer analysis of the emergence of darkness as resource in terms of specification controversies throws light on the underlying dynamics.

\section{Making darkness a place-based resource}

In the economy of qualities (Callon et al., 2002), the place-based resource is a potential for action. It is both an economic and a place-based construction that characterizes and differentiates products and services, giving meaning to a place while contributing to making it attractive (Maillat, 1995). The place-based resource is revealed by an intentional process engaging a collective dynamic of appropriation by regional and local actors in economic, cultural, heritage, scientific, and other registers. A distinction is made between generic resources and specific resources (Colletis \& Pecqueur, 1993, 2005). Specific resources are not reproducible. They are peculiar to a region or local area. Now that regional development and planning policies are part of the paradigm of global environmental change (CISS-Unesco, 2013) the specification process has come to grips with the issues of the restoration of biodiversity and the energy transition. From this perspective, making a resource something specific presupposes directing the ways it is produced and processed towards conserving it, which involves making any use of it as reversible and parsimonious as possible (Vivien et al., 2013). It is a matter of making the scarcity of the resource and its interdependence on other local ecosystems the principle behind its exploitation.

The integrated managerial approach to ecosystem services (Olsson et al., 2006; Ostrom, 2009) is an analytical and methodological framework that also applies to the specification of darkness as resource (Gallaway, 2010, 2015; Stone, 2017; Mitchell \& Gallaway, 2019). But while it is practical and operational, this utilitarian approach to nature based on cost/benefit analysis does not exhaust all relations with night-time and experiences of it. The specification of darkness may rest on an unquantified but objectivizable dimension of the relationship with the night and the well-being that derives from it. This specification process then refers back to the ethics of deep ecology (Næss, 1973). According to Arne Næss, depleting the experience of nature, reducing connections with non-humans - access to the starry night sky, to the night and its fauna - adversely affects one of the conditions for achieving a non-egocentric self. From this perspective, the management of nocturnal ecosystem services provided by darkness is not the ultimate horizon for the development of rural areas but one means among others of giving their users a wider range of choice for experiencing nature (in the sense of biodiversity) and the night. Besides, combating the extinction of the experience of nature is one form of the specification of darkness. It is also one of the areas 
of investigation common to ecologists and geographers for preserving biodiversity (Cazalis \& Prévot, 2019). This area of intervention is essential in creating environmental citizenship. This presupposes taking an eco-centered approach to nature at the core of deep ecology (Dobson 2007) which itself is inseparable from the different forms of attachment to places (Carrel \& Neveu, 2014).

So the specification of darkness can follow an eco-centered approach to nature, at the heart of deep ecology, that is, one of these other scientific and experience-based relations with biodiversity that determine the reconfiguration of rural areas. By reincorporating the sociosphere and the econosphere within the biosphere, the eco-centered approach to biodiversity could partake of the ecologization of the economy within rural areas.

The same applies to the energy transition. The multi-level approach (Geels, 2002) defines the transition as the shift from one sociotechnical regime to another:

"The multi-level perspective argues that transitions come about through interactions between processes at these three levels: (a) niche-innovations build up internal momentum, through learning processes, price/performance improvements, and support from powerful groups, (b) changes at landscape level create pressure on the regime and (c) destabilisation of the regime creates windows of opportunity for niche innovations. The alignment of these processes enables the breakthrough of novelties in mainstream markets, where they compete with the existing regime." (Geels \& Schot, 2007, p. 400).

However, although this systemic approach proposes a multidimensional framework of analysis of the low-carbon transition, this transition cannot be reduced to green growth and the market for "green technologies" (LED, on-demand lighting systems, smart grids, etc.). The transition may also consist in opting for energy savings. Switching off artificial lighting for all or part of the night is a cheap technical solution, but it disrupts many sociocultural representations and habits. Moreover, the multi-level approach does not make conserving biodiversity its object of study and is not forthcoming about the place-based dimension of transitions. Yet, preserving darkness for ecological purposes is a place-based action that interlocks lighting technologies and energy consumption. Any analysis should therefore study the feedback loops induced by allowance for the preservation of biodiversity in the sociotechnical transition process, while showing how this feedback affects public policy making. To do this, it is necessary to identify both problems framing and resolution, the learning processes thereby induced, and the issues of territorial governance. These three elements provide information on the locking and unlocking of the process of specifying darkness as a resource.

\section{Resource specification controversies reconfigure rural areas}

This process of specification of darkness as resource involves changes in representations, conflicts of interest, and power relations that redefine associations and groups. By reference to the sociology of controversies (Latour, 2005), we refer to this process as "specification controversies". Specifying darkness as resource in the paradigm of global environmental change means including the controversy in the opposition between the economicization of ecology and the ecologization of the economy. It also implies connecting up two separately stated phenomena: energy transition and the preservation of biodiversity. This opposition and connection determine the scope of the actor network that is being formed (Akrich et al., 2006). The locking or unlocking of the controversy 
within the network actor depends on the representations and interests of individuals, collectives and institutions acting at different spatial scales and according to different systems and sociocultural references. Specification controversies then enable the emergence of "hidden economic activities and alternatives that contribute to social well-being and the regeneration of the environment" (Gibson-Graham, 2008, p. 618). Rural areas transform into incubation places structured by the specification controversies about darkness. They determine the innovation process, which is a key factor in their sustainable planning and development (Esparcia, 2014). Accordingly, multi-scalar logics, the domestication of European lighting standards, the identification of spaces, species and ecological processes that are sensitive to nocturnal artificial light, all redefine local equilibriums, affect the governance and orient the future of these rural areas, i.e. the direction their development will take. These rural areas - incubation places that are continually being reconfigured - are not enforcement segments of a policy defined outside of them, in a centre-periphery logic. They illustrate how the multidimensional globalization processes are mediated and incorporated into local dynamics. Consequently, they question the top-down logic of governance when it comes to climate and biodiversity (Aykut \& Dahan, 2014).

In other words, bringing to light specification controversies about darkness means creating the conditions for territorial reflexivity (Lapostolle, 2013), which is an inevitable requirement for understanding the challenges involved in transition.

\section{Transdisciplinarity and the place-based transition operator to turn development pathways into a debatable subject}

The analysis and understanding of transition challenges is a field of research built on the combination of a constructivist epistemology and a realist epistemology (Markard et al., 2012) that can be found again in the multiple evidence-based approach (Tengö et al., 2014) as well as in the paring of the research traditions of social geography (Di Méo, 2005; Lussault, 2016) and the ecosystemic approaches of experimental sciences (Buclet, 2015; Barreteau et al., 2016). This rapprochement is a key stage in the transition to a transdisciplinary logic, which posits that the transition towards sustainability belongs to the political domain and "requires inclusive debate and multiple voices. Seen in this way, science and knowledge making become integral to wider conceptions of society and democracy" (Leach et al., 2013). The development of this collective reflexivity approach presupposes that the purposes and values that underlie the action are specified. This critical approach creates the conditions for pluralizing the logics and scales of stating reality and counterbalances - though without neglecting it - the utilitarian and economic analysis of the resource to fit that analysis into a global environmental change approach. It thus looks at other place-based ways of considering the resource in its multiple cultural, ecological, social and political dimensions.

Accordingly, such deconstruction of darkness as resource makes it possible to understand the historical and institutional context it emerges in and develops, and the values and representations of reality it is grounded on, and the spatial scale(s) it is rolled out at. Following this "territorial reflexivity imperative", exposing the conditions for making and specifying the resource is to give the actors and inhabitants of the territory the means to situate themselves along a continuum directed on one hand towards the economicization of ecology and on the other towards the ecologization of the economy.

This reflexivity presupposes a means of instrumentation: the place-based transition operator (PTO). The PTO is dependent on sustainability brokering. Sustainability brokering takes note of the 
decoupling between top-down management of global environmental change "driven by high-level panels, Conferences of Parties, and senior officials meetings [and] the array of innovative grassroots initiatives springing up in farms and forests, villages and municipalities, factories and homes, across the globe" (Leach et al., 2012). To remedy this, it is necessary to combine knowledge of the planetary social and environmental boundaries with an understanding of the particular meanings and objectives of local-scale transitions. New knowledge, new skills and fresh collective choice procedures (Lapostolle et al., 2015) are essential. They permit to take advantage of the innovative capacities of scattered and isolated local initiatives and make generalities of them, that is, to have them change spatial and institutional scales. The PTO is then reflected in institutional innovations arising from transdisciplinary research. But it can only be rolled out by promoting the circulation of knowledge and experience within multi-scalar networks. Such experiences affect opinion as much as the dimensions of sensitivity, affectivity and the imagination. Or then again, the project may, under certain circumstances of participation, cognitively enhance sustainability brokering. In other words, the PTO is only relevant if it operates as a mediator between different representations and perceptions of reality, between different interests and action rationales at the heart of specification controversies. Resolution of these controversies then results in diversified transition trajectories (Rosenbloom, 2017).

Lastly, the PTO serves to reveal what a scientific discipline - geography — can bring when open to transdisciplinary logic. By questioning the meaning of places, through objective and sensory sociocultural approaches, this practice of geography fits in with the multiple base evidence approach that is useful in the analysis and reflexive steering of the socio-ecological transition. Very specifically, geographical studies of the feeling of belonging, of attachment to places can be used to define and characterize the relations between users and resource systems. They thus promote the pairing of analyses bearing on the management of socio-ecosystems and resource specification. When thought of this way, and to take up French geographer Yves Lacoste's words, "geography serves primarily to wage war" (Lacoste, 2014)... on global environmental change. By apprehending the protection of darkness as a point at issue in place-based ecological and energy transitions, our geographical practice contributes to making this environmental and energy niche a lever for transforming development and planning policies for rural areas. It also contributes to the recognition of the conservation of biodiversity and the low-carbon transition as guiding principles for regional development.

\section{Case studies, methodology and framework of analysis}

\section{Case studies}

We analyze the conditions for making darkness a resource in France, in two rural mountain areas which articulate low-carbon transition and biodiversity protection in the service of regional and local development: the Pic $d u$ Midi International Dark Sky Reserve (Pic du Midi IDSR), in the French Pyrenees and the Baronnies provençales Regional Natural Park (Baronnies Provençales RNP) in the southern Alps (fig. 1).

Figure 1.

The Pic du Midi IDSR is in the Hautes-Pyrénées department, Occitanie region. According to the International Dark-sky Association (IDA), a North-American association for the defense of the night sky, an International Dark Sky Reserve is 
"a public or private land possessing an exceptional or distinguished quality of starry nights and nocturnal environment that is specifically protected for its scientific, natural, educational, cultural, heritage and/or public enjoyment. Reserves consist of a core area meeting minimum criteria for sky quality and natural darkness, and a peripheral area that supports dark sky preservation in the core. Reserves are formed through a partnership of multiple land managers who have recognized the value of the natural nighttime environment through regulations and long-term planning. ${ }^{3}$ "

The Pic du Midi de Bigorre, which rises to 2877 meters above sea-level is a Mecca of the Pyrenees. The protection of its starlit sky fits in with already long-standing and locally well-rooted tourist promotion. The Pic du Midi IDSR was institutionally set up on 19 December 2013. It comprises a "core area" of $600 \mathrm{~km}^{2}$, composed of low-density International Union for Conservation of Nature (IUCN) protected areas and a "buffer zone" of $3112 \mathrm{~km}^{2}$, spreading towards the Pyrenean Piedmont. It includes more densely populated zones, for a total of 251 local council areas and 87,500 inhabitants. Being targeted exclusively at the protection of the nocturnal environment, it has been added to the other environmental protection arrangements, without being part of an integrated approach for now.

The Baronnies provençales are located on the boundaries of two regions, for two-thirds in the Drôme department (Auvergne-Rhône-Alpes region) and for one-third in the Hautes-Alpes department (Provence-Alpes-Côte d'Azur region). The Baronnies provençales cover the preAlpine mountain area lying between the Rhône floodplain to the west and the Durance valley to the east, the Drôme catchment basin to the north and Mont Ventoux and the Montagne de Lure to the south. In an area of $2264 \mathrm{~km}^{2}$ with 39,000 inhabitants, there are 130 local council areas, half of which have fewer than 100 inhabitants. The largest of these, Nyons, has fewer than 7500 inhabitants. The recent creation of the Baronnies provençales RNP in 2015 is consistent with an integration logic of multiple schemes for environmental protection across the area.

Both study areas are rural mountain areas shaped by primary sector activities: extensive farming and mixed farming, agro-pastoralism... They sell their output through short supply chains for residents and visitors in the form of local produce covered by collective brand quality schemes protected denomination of origin (PDO), organic... The main outlets for these activities are the tourist sector that structures the local economy by developing a service activity that, to some degree, offsets the decline in former industrial activity. These rural areas promote their ecosystems, their landscapes, their mountain rurality, a spirit of places and a certain art of living. However, the residential base of their economy prevails. Their development has long been built around the capture of a share of redistributed income, retirement pensions and tourist flows that fall within their reach. This local capacity must, however, adapt to the decline in farming, which places a strain on the continued existence of the economic rent derived from the territory and landscape quality.

In the Pyrenees, the warming climate means that tourist flows from winter sports are no longer guaranteed. The tourist industry must rethink its underpinnings and practices (diversification, deseasonalization). So far, it has managed to combine mass tourism and slow tourism, but the crowding-out effect of mass tourism with respect to other activity sectors, notably in the use of building land and the allocation of public and private financial flows is now under debate. It is the sustainability of this type of development that is questioned. The Regional Natural Park authorities in the Baronnies are attempting to curb the decline of the residential economy. The weakening of

$3_{\text {https://www.darksky.org/our-work/conservation/idsp/reserves/ }}$ 
farming that ensures a large proportion of territorial quality leads to encouraging the arrival of new inhabitants and activities that are not directly dependent on tourist flows.

These low-density spaces are structurally marked by a relative shortage of expert knowledge. They have overcome this weakness to some extent by becoming part of environmental protection schemes - national parks, regional natural parks and nature reserves recognized by the IUCN by including their products in collective quality schemes. They also resort to UNESCO and IDA international quality markers. These schemes connect up these areas with networks of national and international experts who, while making the local area the main operator in nature protective actions and the measures that surround them, immerse them in the global countryside.

\section{Methodology}

Our work is a case study that highlights two place-based transition trajectories. It is inspired by anthropological data collection methods. Long immersion has enabled us to join the steering committees and scientific committees of the Pic du Midi IDSR as well as the Baronnies provençales RNP. They enable us access to participating observation, formal interviews and informal discussions with the main actors, but also with minority actors in the process surrounding the emergence of darkness as resource. Working in immersion involves bivouacking, spending nights in mountain shelters, nights of astronomical observations with varied audiences, and presence on village markets to film discussions with customers from the area and elsewhere. The making of darkness as resource can also be observed in the circulation of ideas, collective quality schemes, maps and scientific studies, via the analysis of interactive Internet gateways that create crossnational spaces and networks. The study of the interconnections of spaces and actors and of mediation rationales also contributes to an understanding of how darkness as resource in its relational dimension can launch a trajectory towards sustainability. Alongside this, monitoring changes in national and European norms informs us about how this environmental problem is institutionally defined and treated.

\section{Analytical framework}

Our analytical framework shows how specification controversies over darkness as resource lead to the creation of a place-based transitional operator that interconnects the energy transition and the preservation of biodiversity.

The study of the specification of darkness as resource observes the controversies by which heterogeneous worlds link together to form a network (Callon et al., 2001). These networks play an essential part in place-based transition trajectories and in the way darkness is apprehended. The relationship that local actors maintain with darkness is observed in the process of institutionalizing representations and economic interests in an ad hoc place-based scheme. However, due to the concern for global environmental change, local areas connect up with networks that tie individuals, organizations and institutions together at several organizational scales. It is through such networks that fresh perceptions and definitions of energy transition and biodiversity preservation circulate among local areas. We focus specifically on the gaps between these rapprochements. How does the ecosystemic approach infiltrate and reinforce itself in the logics rural areas development and planning? Through what learning mechanisms, references circulation and social coordination does governance reorient itself towards the restoration of biodiversity combined with transition? Through what institutional arrangements is this matching of action rationales built (Janssen et al., 
2011)? How is the adaptive governance (Folke et al., 2005) of these transition trajectories constructed?

\section{Results and discussion}

The controversies about the specification of darkness as resource are rooted in various territorial trajectories. The notion of trajectory accounts for the diversity of territorial patterns and dynamics (François et al., p. 276). Although the trajectory is structurally integrated into path dependency (North, 1990), bifurcations are nonetheless possible. Making these bifurcations presupposes that the territory 4 is made the subject of a political project that brings about a change in the development and planning logic (Elden 2010, Lapostolle, 2011). The territory is made the subject of a political project - i.e. it is included in the global environmental change paradigm - by way of a placebased transition operator which, in its general principle, trivializes the means for ecosystems preservation in keeping with energy savings.

To account for what happens in these rural spaces as incubation areas, we first present the three specification controversies that run through and interconnect territory actors in the promotion of darkness as a resource. Then we show how a transition operator emerges from these controversies. It opens up a bifurcation in the development trajectory and planning of the local area (fig. 2).

\section{Figure 2}

\section{Specification controversies}

\section{Anthropocentric utilitarian logic}

The specification of darkness as resource constructed by the utilitarian thinking of the anthropocentric conservation of resources postulates a separation between humanity and nature. Besides, it gives precedence to humankind over all other forms of life. This logic is reflected by the "economicization" of the environment, in line with shallow ecology (Naess, 1973) leading to the notions of green growth and ecosystem service management (Ekins, 2002).

In the Pyrenees, the protection of the dark sky is a component of the promotion of the venue's mass tourism marketing. The International dark sky reserve maintains this space within its path dependency. This logic of environment economicization is also found in the implementation of the technical renewal of outside lighting. The lexicometric analysis of the digital mediatization of the Pic du Midi IDSR (Bénos et al., 2016) shows that a large part of the arguments made by the Pic du Midi IDSR actors have to do with the issues related to the conversion of outside lighting and the budget savings resulting from this. However, comprehensive interviews with them also show that the tourism dimension plays an important part in the process of local appropriation of the project. Expectations are expressed in particular in relation to the diversification of the Pic du Midi's drawing power for tourism and its derived products:

"We are doing a lot of work on the starry sky reserve project. Yet, we're not selling the Pyrenees as part of it. If you go up in the skip at present you don't get into the history of the Pyrenees, instead you consume a landscape. And the proof is that people who walk up to the terrace have to pay $€ 10$, I think I'm right in saying. That's too offensive to my liking. This

\footnotetext{
${ }^{4}$ According to Barreteau et al. (2016), we understand the notion of territory as a social construct combining material dimensions - (bio)physical and ecological characteristics of space - and immaterial dimensions - social representations, discourses or images produced in a specific space, which transform space into territory, making it socially and culturally invested.
} 
has been clearly seen with the starry sky reserve project: initially the Pic saw it as an opportunity to communicate and so for more trips up!" [Interview with the senior management of a project area within the Pic du Midi IDSR, March 2013].

Besides, if the concern of the International dark sky reserve promoters were to protect darkness as resource by combating light pollution, the mandatory enforcement of the statute would not require the Pic du Midi to be labeled on the basis of a voluntary move by the local councils. Article R 583-4 of the 12 July 2011 decree in application of the Grenelle Environment lists protected spaces that must take measures to "prevent, reduce and limit nuisances from lighting and energy consumption". However, central government's inertia in enforcing the statute seems to encourage these initiatives of economicization of the environment to the detriment of the ecologization of the economy.

\section{Ecocentric conservation}

The specification logic of darkness as resource is part of the ecocentric conservation of biodiversity. The ecocentric approach aims to protect all living things and the environment for itself. It considers that the anthropocentric approach is the cause of environmental problems, as humans consider nature to be a mere resource to be exploited. The ecocentric approach is reflected in the ecologization of the economy. So, the economic activity is included within the sphere of human activities, which is in turn included in the biosphere. Here, the preservation of nocturnal ecosystems determines the territorial conditions for their promotion, whether commercial or not. Within the local area, the preservation of biodiversity balances out logics of socio-economic promotion. Specifically, within the nocturnal ecosystem, darkness is the necessary asset for providing fundamental ecosystem services (Lyytimaki 2013) such as the pollinating of plants by nocturnal pollinating insects (Macgregor et al., 2019). The specification of darkness as resource presupposes the non-use of artificial light at night: switching lighting off during the period of fruit tree pollination, the breeding season of light-sensitive insects, or the passage of migratory birds (Challéat et al., 2018). These simple enforcement measures do not seem to require any special labeling scheme or zoning to protect the night environment.

Nevertheless, the ecocentric specification of darkness as resource often remains limited to dedicated areas. Extending it to all areas requires mobilizing another spatial model that is reserved by the protected areas model that prevail over the creation of International dark sky. The holistic concept of the ecological network proves relevant (Opdam et al., 2006). This concept was developed on the basis of island biogeography theories (MacArthur and Wilson, 1967) and population dynamics (Levins, 1969). It "allows a shift away from the 'topologic' approach to conservation, involving only protected areas, and to the landscape 'chorological' approach, involving the whole territory" (Battisti, 2003, p. 241). When applied to darkness protection, the "dark ecological network" incorporates International dark sky reserves as "reservoirs of darkness" connected by "dark ecological corridors" (Laforge et al., 2019; Franchomme et al., 2019). The Pyrenees National Park, in conjunction with the Paris Natural History National Museum, the MidiPyrénées natural spaces Conservatory and the Pic du Midi IDSR, is working on defining and characterizing such a dark ecological network on its territory, by identifying a light sensitivity threshold for certain target species of bats, above which their life cycle is disrupted.

While this approach is the result of methodological experimentation, it cannot be considered as a transitional operator. For one thing it is based on a purely expert protocol of spatial analysis that does not include the sensitive and political sociocultural dimensions of attachment to place: its functionalist logic does not address the issue of the sense of place. For another it appears in a 
conservation area — the Pyrenees National Park — whereas we argue that the transition operator, through the coordination and sometimes the representation and interest conflicts it entails, aims at rendering commonplace the forms of preserving ecosystems in all types of areas. It is on these conditions that the scientific concept of "dark ecological network" becomes a place-based transition operator that we name the "Trame noire".

\section{The integrated socio-ecosystemic logic}

We refer to the third specification logic of darkness as resource as the "integrated socioecosystemic approach". Unlike the anthropocentric and ecocentric approaches that are mutually exclusive and involve a principle of hierarchization and subordination of one sphere to another, the socio-ecosystemic approach is holistic. It presupposes the non-hierarchical coordination of social, economic, and ecological components and consecrates the interdependence between development, planning, the preservation of biodiversity, and energy savings. For example, in the Baronnies provençales RNP, the protection of darkness is paired with the protection of biodiversity, through the organization of a national plan for the protection of bats. The Birds Protection League and the Chiroptera Group of Provence are the local associations tasked by central government with heading the action plan in the regions. These associations contribute to defining and promoting darkness as resource within an ecosystem logic. This is materialized in actions for environmental education, in a participative science program to produce data about the evolution of bat populations, and in events on the management of riparian woodlands for bats (regional nature Park officers, consultancy staff, waterways personnel, central government services workers, agents from the national forest department and the national water resources department and wetlands as well as elected representatives).

The Regional Natural Park's management, which is a stakeholder in these actions, is banking on the development of nature tourism to the benefit of both inhabitants and visitors. Darkness as resource then becomes the vehicle for the experiential relationship with nature. However, the accumulation of piecemeal initiatives does not make a development policy. The Regional Natural Park is looking to turn things into a coherent whole, using the fuzzy notion of "nocturnal landscape". The plasticity of this notion allows linking the landscape as a one of ecologists' unit of analysis to the landscape as a public policy instrument. Landscapes can be defined then as "portions of infra-regional spaces where many services or resources are provided by spatial assemblies of different ecosystems" (Lepart \& Marty, 2013, p. 114). The underlying idea is that the landscape thus defined could reframe the human/non-human interactions in a more sustainable perspective. This impacts the making of the place-based project. The Regional Natural Park's charter attests to this:

"To operate an action program in a peripheral zone with a view to securing international recognition of the Park as a preserved nocturnal landscape. To coordinate, with volunteer communities and partners, the management of the peripheral area as the setting for the creation of a "starry villages" scheme, where the objective is to develop sustainable nocturnal tourism and night-time activities. The reduction in lighting goes along with work to promote the market towns, their image, and their nocturnal land, through technical support in terms of lighting scenography and nocturnal landscape. To accompany tourism professionals whose activity takes place or may take place at night time." [Charter of Baronnies provençales RNP, 2015, p. 78].

In the Baronnies provençales Regional Natural Park - and following the integrated socioecosystemic logic — the specification of darkness as resource promotes the non-quantified but 
objectifiable dimension of well-being, which refers to the ethical scope deep ecology (Næss, 1973). According to Næss, to deplete the experience of nature is to reduce one of the conditions of the individuation process because self-realization depends on the connection of humans and nonhumans, a connection that is not always taken into account in local areas projects.

\section{Place-based trajectories and transition operator}

Specification logics are manifested to different degrees in the areas under study. They clash and sound each other out in controversies that are resolved by defining a place-based transition operator. This operator stabilizes the socio-ecosystem dynamics which marks the way for a fresh territorial trajectory. We account for this through the changed perception of the darkness-lighting pair, the actor networks coordination and the territorial system reshaping, and new institutional arrangements.

\section{The changed perception of the darkness/lighting pair}

The changed perception of the darkness/lighting pair is part of a socio-technical controversy over artificial light at night that, since the 1970s, has fitted at international and national scales into the Dark Sky Movement (Challéat et al., 2015). The controversy originally opposes two worlds:environmentalists and technicists. Environmentalists as proponents of a global approach to the nocturnal environment define artificial light as engendering alterations to a natural asset darkness - and as a pollutant, with respect in particular to ecological and health impacts. They advocate extinction of lighting for all or part of the night. Technicists, as proponents of a sectorbased and segmented approach, characterize the problems raised by artificial light as a form of nuisance (Challéat \& Lapostolle, 2014). They defend technical solutions such as the modulation of light intensity at night. Their confrontations, by driving technological change, professionalization, and the renewal of functions dedicated to outside lighting have created the conditions for lighting public spaces differently.

In the Pyrenees and the Toulouse area, the role of amateur astronomers is decisive in considering darkness as a resource. This astronomers' pioneering front began light-pollution measurement campaigns in the late 1990s. It disseminates the earliest maps of nationwide light pollution in France, and in 2008 founded an association to protect the starry sky. As part of the UNESCO's International Year of Astronomy in 2009, this association plans the creation of an International Dark Sky Reserve around the Pic du Midi de Bigorre. It aimed at strengthening the touristic attractiveness of this astronomical observation Mecca, whose scientific activity has been declining since the 1980s. That same year, the Midi-Pyrénées regional council president and the mayor of Toulouse signed a charter initiating the process. The project coalition was extended to the HautesPyrénées power agency, the University of Pau and Pays de l'Adour. Two researchers at this university have established links with the IDSR of Mont Mégantic in Quebec, in order to exchange starry sky-friendly practices - e.g. around the aesthetic value of the dark sky, or the concern for energy saving through new lighting technologies. In December 2013, the Pic du Midi IDSR was made official. The tourist development of the Pic has become a leading economic challenge. Scientific activity continues there and alongside it tourism for amateur astronomers wishing to use professional instruments has proved a genuine success. At the same time, a few peripheral communities make the protection of their nocturnal environment the main issue of their planning and tourist development policy. They install new LED luminaries, sometimes switch off the lighting, organize evenings for night sky observation. As pioneers among the 251 council areas of 
the International Dark Sky Reserve, they serve as a demonstrator in the area for the areas that follow suit.

In the Baronnies provençales, consideration of darkness as resource is primarily the doing of a private entrepreneur who is an amateur astronomer and local correspondent for the ANPCEN. This is a computer scientist by profession, having long worked abroad. After seven years of work (including a part funded by the European Regional Development Fund for private rural development initiatives), he inaugurated the Baronnies provençales Observatory in January 2013. Open all year round to tourists and enlightened amateurs with observation instruments, the observatory collaborates with Russia's Academy of Science, for which it conducts research on exoplanets. This private entrepreneur advocates night sky protection. By playing his part as local correspondent for the ANPCEN, he and local elected officials have promoted the "Starry Cities \& Villages" scheme. This way, he has moved closer to the coalition of local actors working on the plans for the Baronnies provençales RNP. He persuaded the authorities of the Park (officially inaugurated in 2015) to make protection of the night sky an issue and a line of sustainable development of the area. The Regional natural park is thus part of a national dynamic encouraged by the Ministry for Ecology which, on the basis of a partnership between the ANPCEN and the Federation of French Regional Natural Parks, combats light pollution and its effects on darkness and biodiversity. Within the Park, the night dossier is handled by a landscape architect, who advocates an extended understanding of the protection of the nocturnal environment and its biodiversity. The landscape dimension of the night fits in with the Park's ambition to make the landscape a structuring factor in its action for the development and planning of the territory.

\section{Actor network coordination, shaping of the territorial system, and proximity logics}

In the Pic du Midi IDSR, the associations, experts and political actors network has been coordinated around common objectives: eco-friendly lighting practices and the installation of sustainable and economical equipment. Every year several million euro are invested in converting outside lighting. This expenditure materializes the commitment of the local councils, the Hautes-Pyrenees Electricity Office, the French power utility EDF, and the Midi-Pyrénées Environment and Energy Management Agency. François Fortassin's (senator for the Hautes-Pyrénées since 2001) leadership is politically decisive in crystallizing this commitment. In order to maintain collective action, to coordinate it over the longer term, a whole array of project-objects has been developed. To supplement the standard technical specifications - and as a follow-up to the exchange of experience with the Mont Mégantic IDSR in Québec - the Pic du Midi IDSR has published a Lighting Guide for local authorities, technicians, and a Practical Lighting Guide - Starry Sky for the inhabitants of the valleys. More original is the use of participatory science to enroll a wider audience through the "Star guardians" operation. This mobilizes mountain refuge guardians for the twin purpose of sensitizing the population and tourists about protecting the dark sky and gathering long-term metrological data about night sky quality. Through an operation targeting a wide audience, the International dark sky reserve then plays a role of experimentation especially for light pollution measurement protocols.

In line with its regulatory missions, the Baronnies provençales Regional Natural Park development project is based on the preservation and promotion of a rich but threatened natural and cultural heritage. In the context of this area's sensitive equilibrium, it hosts, educates, and informs the public. It carries out experimental actions for the protection of the natural and cultural environments in line with national and European strategies for sustainable development and it contributes to research programs From the outset, one of the first initiatives was to create the 
Vautours en Baronnies (vultures) association in 1993, which brings together a number of local actors: livestock farmers, elected officials, naturalists, hunters as well as technicians of the Office National des Forêts and the Office National de la Chasse et de la Faune Sauvage. The study association for the creation of a Regional Natural Park was formed in 2001, at the instigation of an ad hoc planning agency that was heading a European "Leader + " project including 180 local council areas. In 2003, the Rhône-Alpes and Provence-Alpes-Côte d'Azur regions undertook a feasibility study for an interregional nature park. In 2007, more than 650 associations and other local, departmental, regional, and national organizations were invited to discuss the creation of the Regional Natural Park.

Landscape structures protection is the guideline of the development plan. It covers control over changes in urbanization, maintaining farmland areas and crops diversity, conserving the outstanding sites of the river gorges, managing the forests to promote woodland diversity, promoting the specific features of the area for tourism, and promoting the exceptional quality of its night sky. Landscape protection involves the Regional Natural Park's interdisciplinary team within several programs that are all nodes of connections with professional and expert networks. Notable among these is an applied research program on the notion of territorial resource in relation with the Regional natural parks Rhône-Alpes network and the University of Grenoble Pacte research laboratory. Another program, in partnership with the Ecole nationale supérieure du paysage de Versailles, from which one of the development agents of the Park's team comes, identifies and characterizes the various landscapes of the Baronnies provençales. An Area of Protected Urban and Landscape Architectural Heritage is under study. Teaching workshops are associated with it and fit into the environmental education action programs.

The concern to mobilize the local society is an action principle for the Regional Natural Park's team. Each of the programs is built around the ambition of participating, understood as "taking part", marking one's contribution and receiving one's share (Zask, 2011). In other words, the Park users are invited at public meetings or workshops to integrate working groups throughout the Park. The Park team understands "taking part" as creating the conditions for debate and collective action, enabling all Park's users to make a stand and defend their interests and representations. That presupposes practical knowledge of the places and persons throughout the area. For many participants, making one's contribution means fostering development objectives, thanks to their knowledge and abilities. For users, receiving one's share means ensuring a balanced development of the different facets and places of the territory for the benefit of a residential economy that controls tourist flows. It means preserving what binds participants, namely the natural and cultural heritage. The participatory approach is called for because it legitimizes the Park, which in its early days was subject to political uncertainty and the interplay of regional council majorities that would use subsidies to influence its orientation and action. By promoting the participation of the local community, that rubs shoulders with others, experts for example, that have other forms of knowledge and representation, the Baronnies provençales Regional Natural Park's team, makes this approach an experiment in training and education in environmental citizenship. It thus contributes to rooting the objective of preservation within the local community.

This approach is noteworthy when it comes to promoting the nocturnal environment. Taking consideration of the nocturnal environment might seem to be a new craze for the Park's team and the scientific committee, which little involves its users. Socializing the challenge of combating light pollution, sharing the concern for preserving darkness in a low-density area, promoting switching-off outside lighting also nurtures the fear of sliding deeper into hyper-rurality. 
Accordingly, regulating outside lighting for this purpose is not something that can be decreed, and does not prevail through the scientific argument alone. Its authority is not self-evident for the Park's users and inhabitants whose average standard of living is comparatively low. Saving on outside lighting to save bats or gaze at stars is not the primary concern of the many people who do not make a living from these activities. "To make emerge a nocturnal practice in the area and its heritage items, as an original resource and natural quality to promote, through astronomy, art, lighting, the understanding of landscape and nature at night"5 may feel somewhat like pie in the sky. For the Regional Natural Park's team, the construction of a shared sense of preservation of the night time environment is conceived of as an experience that involves the "awakening of the senses", the creation of an exemplary zone for the control of outside lighting. Thereby, it makes it possible to preserve night sky quality, review the night time staging of outstanding or historical monuments and operate the landscaping of the night. All these actions are spread around the Park. With a view to applying for IDA recognition, they are widening their scope so as to coordinate the reduction in lighting with local authorities and voluntary partners - the "Starry cities and villages" area councils. The Park provides technical support for staging outside lighting and the nighttime landscape.

\section{Local modification of institutional arrangements}

The multiple meanings of the dark resource fuel specification controversies. The social learnings at work in these controversies lead to the creation of "flexible institutions that can adjust and reorganize in response to changes in ecosystems" (Cumming et al., 2006). These institutional arrangements stem from the transdisciplinary logic framing the dialogue between concepts (dark ecological network and landscape), the biophysical density of the territory, and the expression of the representations and interests that permeate it. In other words, the specifications controversies find an outcome in the institutionalization of the Trame noire and nighttime landscape.

\section{In the Pyrenees, the Trame noire as a place-based transition operator}

The Pic du Midi IDSR is structured according to a centre-periphery logic, which is standard in the creation of protected areas with respect to IUCN rationales. Its local marketing primarily promotes the Pic du Midi hot spot. The Pic du Midi IDSR negotiates little if at all with Toulouse Métropole to reduce the light halo from the region's capital. However, it does work with the Pyrenees national park to move from localized sectoral protection — the dark sky around the Pic du Midi observatory - to comprehensive territorial protection. The instrument of this rapprochement, for crossfinancing opportunities, while binding with Parks governance, is the Trame noire. The Trame noire is the necessary mediator for reconciling two types of darkness specification: the anthropocentric utilitarianism for the Pic du Midi IDSR, and ecocentric conservation for the Pyrenees national park. The Trame noire, the place-based transition operator, is the instrument of governance that connects the ecosystemic unit of analysis - the dark ecological network - with the territorial project. It marks the institutional recognition of the socio-ecosystemic approach of the territory through its various stakeholders. But, at its embryonic stage, it stems from an expert protocol that sets too much store by the ecological dimension, at the expense of the social dimension. In order to fully play its part as a place-based transition operator and to make it commonplace to consider darkness protection as resource, from the outset the Trame noire must incorporate the multiple representations of and interests in the territory. It must therefore provide answers to decisive practical questions. For example, how can the logic of tourist development — posted by the Pic du

\footnotetext{
${ }^{5}$ Charter of Baronnies provençales RNP, 2015.
} 
Midi IDSR and measured by the number of trips to the summit for the night (little concerned with the anthropic pressure generated by these flows) - be combined with the logic of comprehensive preservation of the Pyrenees National Park?

\section{In the Baronnies provençales, nighttime landscape as a transition operator}

In early 2015, the creation of the Baronnies Provençales Regional Nature Park was a determining factor in perpetuating the rent from territorial quality. By making landscape logic a structuring feature of the territorial trajectory, the Park management, which is part of a network logic with the neighboring Regional Natural Parks, gives a new orientation to the development project. The experience of nature and landscape is one of the factors redefining how the territory is inhabited. This tends towards the promotion of environmental citizenship, going beyond the visitor/visited divide. Indeed, "environmental citizenship [...] assumes that people can actually learn something, learn how to be other-regarding and how to consider the collective interest. [...] So, environmental citizenship tries to take seriously people's capacity for ethical and morally informed action." (Dobson et al., 2014, p. 140).

The promotion of darkness as resource derives from this long-term political and ethical purpose, based on a socio-ecosystemic approach. Accordingly, the Park management queries the meaning of place (Williams \& Stewart, 1998; Stedman, 2003; Davenport \& Anderson, 2005; Brown \& Raymond, 2007; Soini et al., 2012) and considers the landscape as the underpinning of a strong attachment to place. For the park authorities, the landscape is a vehicle for sensitive (culturally, politically and scientifically) objective experience and learning that values this space where geological, climatic, and biogeographic events have long been inscribed - a space where animal and plant species live and breed. These human, animal and plant populations contribute to landscape dynamics. In this landscape dynamic, this is the way Park authorities understand recognizing darkness as resource: seeking to "develop the night-time practice of the territory", making public and questionable the cultural and regulating ecosystem services provided by darkness (MEA, 2005; Chan et al., 2012). Giving an ethical and political value to these ecosystem services, which are largely ignored by the general public, involves mobilizing the nocturnal landscape, a notion recognized by French law since 2016. Yet, it remains sufficiently vague to aggregate various and diverse action logics and representations for the place-based preservation of darkness.

The nocturnal landscape is also addressed in its social consistency (Debarbieux, 2007). Shaped by work, it is the place and the product of daily labor. It is also perceived as work in the artistic sense, worthy of being heritagized; it becomes a monument, creates jobs that go into its design, operation, and its upkeep-restoration, while remaining a matter for professionals. Audiences are reduced to categories of users without power, to mere tax payers or consumers. With the logic of participation in the work within the Regional natural park, the nocturnal landscape becomes a political project: a public space oriented towards a transition that creates tension between the economic, aesthetic and environmental approaches and implications of landscape. It is not only a method, a framework of analysis and constitution, but also a transition operator in the sense that environmental citizenship, operationalized within the Regional natural park, presupposes a scientifically and ethically enlightened collective action. It is in the daily workings of the elaboration of environmental citizenship - a path fraught with pitfalls because of the representations, habits, and interests that it upsets - that the night time landscape becomes a transition operator, a vector for learning and sensory experience of a territory that thinks of itself as a socio-ecosystem. This view 
of territory is a form of implementing political ecology without which the ecologization of the economy seems like a long way off.

\section{Conclusion}

The aim of this paper has been to show how, through the emergence of "darkness as resource", the restoration of biodiversity and the energy transition become guidelines in regional development. In the rural areas studied, innovation is to think of darkness as a specific resource that connects energy transition and biodiversity restoration. This socio-technical innovation is structured by a controversy among three territorial processes of specification of darkness as a resource. The first, following an anthropocentric utilitarian logic, is part of the economicization of the environment in the line of shallow ecology, which is reflected by the notions of green growth and ecosystemic services management. The second, following a logic of ecocentric conservation, is part of the radical ecologization of the economy in keeping with deep ecology: it dovetails sociosphere and econosphere within the biosphere. The third process follows an integrated socio-ecosystemic logic by validating the interdependence between development, planning, biodiversity preservation and energy saving.

By escaping path dependency to some extent, rural areas become incubation areas, that is spaces for resolving this controversy that are reflected in a transition operator enabling the territory to take a new development and planning trajectory. For the transition operation to form a Trame noire or a nocturnal landscape and set up the conservation of biodiversity and the energy transition as the normal mode for planning policies, it is vital they become commonplace. This is only possible with the emergence of participation (i.e. taking part, making one's contribution and receiving one's share) which is constitutive of environmental citizenship. This environmental citizenship questions the sense of places and the exercise of power that is deployed there. In other words, there can be no environmental citizenship without territorial reflexivity. For us, this is an essential research perspective so that social geography, practiced in a transdisciplinary way, can contribute to fight light pollution and global environmental change. 


\section{References}

Akrich, M., M. Callon, and B. Latour. 2006. Sociologie de la traduction: textes fondateurs (Sociology of translation: founding texts). Paris, France: Presses des Mines.

Aykut, S. C., and A. Dahan. 2014. La gouvernance du changement climatique. Anatomie d'un schisme de réalité (Climate change governance. Anatomy of a schism of reality). In Le gouvernement des technosciences. Gouverner le progrès et ses dégâts depuis 1945 (The government of technosciences. Governing progress and its damage since 1945), ed. D. Pestre, $97-$ 132. Paris, France: La Découverte.

Azam, C., I. Le Viol, J.-F. Julien, Y. Bas, and C. Kerbiriou. 2016. Disentangling the relative effect of light pollution, impervious surfaces and intensive agriculture on bat activity with a nationalscale monitoring program. Landscape Ecology 31 (10):2471-2483. doi: 10.1007/s10980-0160417-3.

Barreteau, O., D. Giband, M. Schoon, J. Cerceau, F. DeClerck, S. Ghiotti, T. James, V. Masterson, R. Mathevet, S. Rode, F. Ricci, and C. Therville. 2016. Bringing together social-ecological system and territoire concepts to explore nature-society dynamics. Ecology and Society 21 (4):42. doi: 10.5751/ES-08834-210442.

Battisti, C. 2003. Habitat fragmentation, fauna and ecological network planning: Toward a theoretical conceptual framework. Italian Journal of Zoology 70 (3):241-247. doi: $10.1080 / 11250000309356524$.

Bennie, J., J. P. Duffy, T. W. Davies, M. E. Correa-Cano, and K. J. Gaston. 2015. Global trends in exposure to light pollution in natural terrestrial ecosystems. Remote Sensing 7 (3):2715-2730. doi: $10.3390 /$ rs 70302715 .

Bénos, R., S. Challéat, D. Lapostolle, J. Milian, and T. Poméon. 2016. Considérer la nuit étoilée. La construction d'une ressource touristique territoriale : la Réserve internationale de ciel étoilé du pic du midi de Bigorre (Consider the starry night. The construction of a territorial tourist resource: the Pic du Midi International dark sky reserve). In Nouveaux territoires touristiques : Invention, reconfigurations, repositionnements (New tourist territories: Invention, reconfigurations, repositioning), ed. M. Delaplace and M. Gravari Barbas, 55-82. Quebec City, Quebec, Canada: Presse Universitaire du Québec.

Buclet, N. 2015. Essai d'écologie territoriale. L'exemple d'Aussois en Savoie (Essay on territorial ecology. The example of Aussois in Savoie). Paris, France: CNRS Éditions.

Callon, M., P. Lascoumes, and Y. Barthe. 2001. Agir dans un monde incertain. Essai sur la démocratie technique (Acting in an uncertain world. Essay on technical democracy). Paris, France: Seuil.

Callon, M., C. Méadel, and V. Rabeharisoa. 2002. The economy of qualities. Economy and society 31 (2):194-217. doi: 10.1080/03085140220123126.

Carrel, M., and C. Neveu. 2014. Citoyennetés ordinaires. Pour une approche renouvelée des pratiques citoyennes (Ordinary citizenships. For a renewed approach to citizen practices). Paris, France: Karthala. 
Cazalis, V., and A.-C. Prévot. 2019. Are protected areas effective in conserving human connection with nature and enhancing pro-environmental behaviours? Biological Conservation 236:548-555. doi: 10.1016/j.biocon.2019.03.012.

Challéat, S. 2018. Le socioécosystème environnement nocturne: un objet de recherche interdisciplinaire (The night-time environment social-ecological system: an interdisciplinary research topic). Natures Sciences Sociétés (Natures Sciences Societies) 26 (3):257-269. doi: $10.1051 / \mathrm{nss} / 2018042$.

2019. Sauver la nuit. Comment l'obscurité disparaît, ce que sa disparition fait au vivant, et comment la reconquérir (Save the night. How darkness disappears, what its disappearance does to the living, and how to regain it). Paris, France: Premier Parallèle.

Challéat, S., and D. Lapostolle. 2014. (Ré)concilier éclairage urbain et environnement nocturne : les enjeux d'une controverse socio-technique (Reconciling urban lighting and the nocturnal environment: the issues of a sociotechnical controversy). Natures Sciences Sociétés (Natures Sciences Societies) 22 (4):317-328. doi: 10.1051/nss/2014045.

- 2018. Getting night lighting right taking account of nocturnal urban uses for better-lit cities. Metropolitics. 2 November 2018. URL: https:/www.metropolitiques.eu/Getting-NightLighting-Right.html. Translated by Oliver Waine.

Challéat, S., D. Lapostolle, and J. Milian. 2018. The night-time environment in French mountain areas. A resource and a transition operator towards sustainability, Journal of Alpine Research | Revue de géographie alpine 106 (1). doi: 10.4000/rga.3895.

Challéat, S., and T. Poméon. 2019. "And what do you do with five-hundred million stars?" Assessment of darkness and the starry sky, values and integration in regional planning. In Locating Value. Theory, Application and Critique, ed. G. Hoskins and S. Saville. Abingdon-on-Thames, United Kingdom: Taylor \& Francis Books.

Chan, K. M. A., T. Satterfield, and J. Goldstein. 2012. Rethinking ecosystem services to better address and navigate cultural values, Ecological Economics, 74:8-18.

Colletis, G., and B. Pecqueur. 1993. Intégration des espaces et quasi intégration des firmes : vers de nouvelles rencontres productives (Integration of spaces and near integration of firms: towards new productive encounters). Revue d'Économie Régionale et Urbaine (Review of Regional and Urban Economy) 489-508.

2005. Révélation de ressources spécifiques et coordination située (Revelation of specific resources and situated coordination). Économie et Institutions (Economy and Institutions) 6 (7): 51-74. URL: http://journals.openedition.org/ei/900. doi: 10.4000/ei.900.

CISS-Unesco (International Social Science Council). 2013. World social science report, 2013 : changing global environments. Paris, France: Unesco.

Cumming, G. S., D. H. M. Cumming, and C. L. Redman. 2006. Scale mismatches in socialecological systems: causes, consequences, and solutions. Ecology and Society 11 (1), 14. URL: http://www.ecologyandsociety.org/vol11/iss1/art14/

Davenport, M. A., and D. H. Anderson. 2005. Getting from sense of place to place-based management. An interpretive investigation of place meanings and perceptions of landscape change. Society and natural resources 18 (7):625-641. 
Debarbieux, B. 2007. The Political Meaning of Landscape (Through the Lens of Hannah Arendt's The Human Condition). In The Place of Landscape, ed. J. Malpas, 131-149. Cambridge, United Kingdom: MIT Press.

Di Méo, G. 2005. L'espace social. Lecture géographique des sociétés (The social space. Geographical reading of societies). Paris, France: Armand Colin.

Dobson, A. 2007. Environmental citizenship: towards sustainable development. Sustainable development 15 (5):276-285. doi: 10.1002/sd.344.

Dobson, A., L. Semal, M. Szuba, and O. Petit. 2014. Andrew Dobson: trajectories of green political theory. Interview by Luc Semal, Mathilde Szuba and Olivier Petit, Natures Sciences Sociétés 22 (2):132-141.

Duffy, J. P., J. Bennie, A. P. Duran, and K. J. Gaston. 2015. Mammalian ranges are experiencing erosion of natural darkness. Scientific Reports 5:12042. doi: 10.1038/srep12042.

Edensor, T. 2013. Reconnecting with darkness: gloomy landscapes, lightless places. Social \& Cultural Geography 14 (4):446-465. doi: 10.1080/14649365.2013.790992.

- 2015. The gloomy city: Rethinking the relationship between light and dark. Urban studies 52 (3):422-438. doi: 10.1177/0042098013504009.

2017. From light to dark. Daylight, illumination, and gloom. Minneapolis, Minnesota: University of Minnesota Press.

Ekins, P. 2002. Economic growth and environmental sustainability: the prospects for green growth. London, United Kingdom: Routledge.

Elden, S. 2010. Land, terrain, territory. Progress in human geography 34 (6):799-817.

Esparcia, J. 2014. Innovation and networks in rural areas. An analysis from European innovative projects. Journal of Rural Studies 34:1-14. doi: 10.1016/j.jrurstud.2013.12.004.

Folke, C., T. Hahn, P. Olsson, and J. Norberg. 2005. Adaptive governance of social-ecological systems. Annual Review of Environment and Resources 30:441-473. doi: 10.1146/annurev.energy.30.050504.144511.

Fouquet, R., and P. J. Pearson. 2006. Seven centuries of energy services: The price and use of light in the United Kingdom (1300-2000). The Energy Journal 27 (1):139-177.

Franchomme, M., C. Hinnewinkel, and S. Challéat. 2019. La trame noire, un indicateur de la place de la nature dans l'aménagement du territoire. Pratiques et motivations des communes de la métropole lilloise (The trame noire, an indicator of the place of nature in land use planning. Practices and motivations of the municipalities of the Lille European Metropolis). Bulletin de l'Association de Géographes Français (Bulletin of the Association of French Geographers) 2019 (2):161-180.

François, H., M. Hirczak, and N. Senil. 2013. From Resource to Trajectory: What Strategies for Local Development? Géographie, économie, société 15 (3):267-284.

Gallaway, T. 2010. On light pollution, passive pleasures, and the instrumental value of beauty. Journal of Economic Issues 44 (1):71-88. doi: 10.2753/JEI0021-3624440104

. 2015. The value of night sky. In Urban Lighting, Light Pollution and Society, ed. J. Meier, U. Hasenöhrl, K. Krause and M. Pottharst, 267-283. London, United Kingdom: Routledge. 
Gaston, K. J., J. Bennie, T. W. Davies, and J. Hopkins. 2013. The ecological impacts of nighttime light pollution: a mechanistic appraisal. Biological Reviews 88 (4):912-927. doi: 10.1111/brv.12036.

Geels, F. W. 2002. Technological transitions as evolutionary reconfiguration processes: a multilevel perspective and a case-study. Research Policy 31 (8):1257-1274. doi: 10.1016/S00487333(02)00062-8.

Geels, F. W., and J. Schot. 2007. Typology of sociotechnical transition pathways. Research policy 36 (3):399-417. doi: 10.1016/j.respol.2007.01.003.

Gibson-Graham, J. K. 2008. Diverse economies: performative practices for 'other worlds'. Progress in Human Geography 32 (5):613-632. doi: $10.1177 / 0309132508090821$.

Gwiazdzinski, L. 2009. Chronotopies. L'événementiel et l'éphémère dans la ville des 24 heures (Chronotopia. The happening and the ephemeral in the 24 hour city). Bulletin de l'Association de géographes français (Bulletin of the Association of French Geographers) 2009 (3):345-357.

Hölker, F., C. Wolter, E. K. Perkin, and K. Tockner. 2010. Light pollution as a biodiversity threat. Trends in ecology \& evolution 25 (12):681-682. doi: 10.1016/j.tree.2010.09.007.

Isobe, S., and H. Kosai. 1998. Star watching observations to measure night sky brightness. In Preserving The Astronomical Windows. Proceedings of Joint Discussion number 5 of the 23rd General Assembly of the International Astronomical Union held in Kyoto, Japan 22-23 August 1997, ed. S. Isobe and T. Hirayama, 175-184. ASP Conference Series, Vol. 139.

Janssen, M. A., F. Bousquet, and E. Ostrom. 2011. A multimethod approach to study the governance of social-ecological systems, Natures Sciences Sociétés (Natures Sciences Societies) 19 (4):382-394. doi: 10.1051/nss/2011135.

Kahn, P. H. 2002. Children's affiliations with nature: Structure, development, and the problem of environmental generational amnesia. In Children and nature. Psychological, sociocultural, and evolutionary investigations, ed. P. H. Kahn and S. R. Kellert, 93-116. Cambridge, Massachussets: The MIT Press.

Knop, E., L. Zollera, R. Rysera, C. Gerpea, M. Horlera, and C. Fontaine. 2017. Artificial light at night as a new threat to pollination. Nature 548:206-209. doi: 10.1038/nature23288.

Kyba, C. C., and F. Hölker. 2013. Do artificially illuminated skies affect biodiversity in nocturnal landscapes? Landscape Ecology 28 (1637). doi: 10.1007/s10980-013-9936-3.

Kyba, C. C., T. Kuester, A. S. de Miguel, K. Baugh, A. Jechow, F. Hölker, J. Bennie, C. D. Elvidge, K. J. Gaston, and L. Guanter. 2017. Artificially lit surface of Earth at night increasing in radiance and extent. Science Advances 3 (11):e1701528. doi: 10.1126/sciadv.1701528.

Lacoste, Y. 2014. La géographie, ça sert, d'abord, à faire la guerre (Geography serves firstly to wage war). Paris, France: La Découverte.

Laforge, A., J. Pauwels, B. Faure, Y. Bas, C. Kerbiriou, J. Fonderflick, and A. Besnard. 2019. Reducing light pollution improves connectivity for bats in urban landscapes. Landscape Ecology 34 (4):793-809. doi: 10.1007/s10980-019-00803-0.

Lapostolle, D. 2013. La recomposition des formes bureaucratiques dans le développement territorial. Ingénierie territoriale et intermédiations dans les territoires de projet (The 
Recomposition of Bureaucratic Forms in Territorial Development. Territorial Engineering and Intermediation in Project Territories), Revue Intervention Economique/Papers in Political Economy 48 (2013). doi: 10.4000/interventionseconomiques.2043.

Lapostolle, D., S. Challéat, J. Milian, and P.-O. Dupuy. 2015. L'appropriation de la transition énergétique par la protection des ressources environnementales nocturnes : expériences dans les Pyrénées et les Alpes du sud (The appropriation of the energy transition for the protection of nighttime environmental resources: experiences from the Pyrenees and the southern Alps). Géocarrefour 91 (1):351-360. doi: 10.4000/geocarrefour.9967.

Latour, B. 2005. Reassembling the social: an introduction to actor-network-theory. Oxford, New York: Oxford University Press.

Leach, M., K. Raworth, and J. Rockström. 2013. Between social and planetary boundaries: Navigating pathways in the safe and just space for humanity. In World Social Science Report, Changing Global Environments, ed. ISSC \& UNESCO Publishing, 84-89.

Leach, M., J. Rockström, P. Raskin, I. Scoones, A. C. Stirling, A. Smith, J. Thompson, E. Millstone, A. Ely, E. Arond, C. Folke, and P. Olsson. 2012. Transforming innovation for sustainability. Ecology and Society 17 (2):11. doi: 10.5751/ES-04933-170211.

Lepart, J., and P. Marty. 2013. Évaluer la durabilité des paysages (Assess the sustainability of landscapes). In L'évaluation de la durabilité (The assessment of sustainability), ed. F.-D.Vivien, J. Lepart and P. Marty, 113-134. Versailles, France: Quæ.

Levins, R. 1969. Some demographic and genetic consequences of environmental heterogeneity for biological control. American Entomologist 15 (3):237-240. doi: 10.1093/besa/15.3.237.

Lussault, M. 2016. L'Homme spatial. La construction sociale de l'espace humain (The man in space. The social construction of the human space). Paris, France: Le Seuil.

Lyytimäki, J. 2013. Nature's nocturnal services: light pollution as a non-recognised challenge for ecosystem services research and management. Ecosystem Services 3:e44-e48. doi: 10.1016/j.ecoser.2012.12.001.

MacArthur, R. H., and E. O. Wilson. 1967. The theory of island biography. Princeton, New Jersey: Princeton University Press.

Maillat, D. 1995. Territorial dynamic, innovative milieus and regional policy. Entrepreneurship \& Regional Development 7 (2):157-165. doi: 10.1080/08985629500000010.

Mallet, S. 2009. Des plans-lumière nocturnes à la chronotopie. Vers un urbanisme temporal (From night lighting plans to chronotopia. Towards a temporal urbanism). Doctoral dissertation, Paris Est University.

McDonald, R. I., R. T. Forman, P. Kareiva, R. Neugarten, D. Salzer, and J. Fisher. 2009. Urban effects, distance, and protected areas in an urbanizing world. Landscape and Urban Planning 93 (1):63-75. doi: 10.1016/j.landurbplan.2009.06.002.

Macgregor, C. J., M. J. Pocock, R. Fox, and D. M. Evans. 2019. Effects of street lighting technologies on the success and quality of pollination in a nocturnally pollinated plant. Ecosphere 10 (1). doi: 10.1002/ecs2.2550.

Markard, J., R. Raven, and B. Truffer. 2012. Sustainability transitions: An emerging field of research and its prospects. Research policy 41 (6):955-967. doi: 10.1016/j.respol.2012.02.013. 
Millennium Ecosystem Assessment. 2005. Ecosystems and human well-being: synthesis. Washington, DC.

Miller, J. R. 2005. Biodiversity conservation and the extinction of experience. Trends in Ecology and Evolution 20:430-434.

Mitchell, D., and T. Gallaway. 2019. Dark sky tourism: economic impacts on the Colorado Plateau Economy, USA. Tourism Review. 74 (4):930-942. doi: 10.1108/TR-10-2018-0146.

Næss, A. 1973. The shallow and the deep, long-range ecology movement. A summary. Inquiry 16 (1):95-100. doi: 10.1080/00201747308601682.

North, D. 1990. Institutions, Institutional Change and Economic Performance. Cambridge, United Kingdom: Cambridge University Press.

Olsson, P., L. Gunderson, S. Carpenter, P. Ryan, L. Lebel, C. Folke, and C. S. Holling. 2006. Shooting the rapids: navigating transitions to adaptive governance of social-ecological systems. Ecology and Society 11 (1). URL: http://www.ecologyandsociety.org/vol11/iss1/art18/.

Opdam, P., E. Steingrover, and S. Van Rooij. 2006. Ecological networks: A spatial concept for multi-actor planning of sustainable landscapes. Landscape and Urban Planning 75 (3):322-332. doi: 10.1016/j.landurbplan.2005.02.015.

Ostrom, E. 2009. A general framework for analyzing sustainability of social-ecological systems. Science 324 (5939):419-422.

Pyle, R. M. 1978. The extinction of experience. Horticulture 56:64-67.

Riegel, K. W. 1973. Light pollution: outdoor lighting is a growing threat to astronomy. Science 179 (4080):1285-1291. doi: 10.1126/science.179.4080.1285.

Rosenbloom, R. 2017. Pathways: An emerging concept for the theory and governance of lowcarbon transitions. Global Environmental Change 43:37-50. doi: 10.1016/j.gloenvcha.2016.12.011.

Scott, W. R. 1995. Institutions and organizations. Ideas, Interests, and Identities. Thousand Oaks, California: Sage Publications.

Shaw, R. 2015. Night as Fragmenting Frontier: Understanding the Night that Remains in an era of 24/7. Geography Compass 9 (12):637-647. doi: 10.1111/gec3.12250.

2018. The nocturnal city. Abingdon-on-Thames, United Kingdom: Routledge.

Soga, M., and K. J. Gaston. 2016. Extinction of experience: the loss of human-nature interactions. Frontiers in Ecology and the Environment 14 (2):94-101. doi: 10.1002/fee.1225.

Soini, K., H. Vaarala, and E. Pouta. 2012. Residents' sense of place and landscape perceptions at the rural-urban interface. Landscape and Urban Planning 104 (1):124-134.

Stedman, R. C. 2003. Is it really just a social construction? The contribution of the physical environment to sense of place. Society \& Natural Resources 16 (8):671-685.

Stevens, R. G., and Y. Zhu. 2015. Electric light, particularly at night, disrupts human circadian rhythmicity: is that a problem? Philosophical Transactions of the Royal Society B: Biological Sciences 370 (1667):20140120. doi: 10.1098/rstb.2014.0120. 
Stone, T. 2017. The Value of Darkness: A Moral Framework for Urban Nighttime Lighting. Science and Engineering Ethics 24:607-628. doi: 10.1007/s11948-017-9924-0.

Tengö, M., E. S. Brondizio, T. Elmqvist, P. Malmer, and M. Spierenburg. 2014. Connecting diverse knowledge systems for enhanced ecosystem governance: the multiple evidence base approach. Ambio 43 (5):579-591. doi: 10.1007/s13280-014-0501-3.

Vivien, F., J. Lepart, and P. Marty. 2013. L'évaluation de la durabilité (The assessment of sustainability). Versailles, France: Quæ.

Williams, D. R., and S. I. Stewart. 1998. Sense of place: An elusive concept that is finding a home in ecosystem management. Journal of forestry 96 (5):18-23.

Woods, M. 2007. Engaging the global countryside: globalization, hybridity and the reconstitution of rural place. Progress in Human Geography 31 (4):485-507. doi: 10.1177/0309132507079503.

Zask, J. 2011. Participer. Essai sur les formes démocratiques de la participation (Participate. Essay on democratic forms of participation). Lormont, France: Le Bord de l'Eau.

Zissis, G., and S. Kitsinelis. 2009. State of art on the science and technology of electrical light sources: from the past to the future. Journal of Physics D: Applied Physics 42 (17):173001. doi:10.1088/0022-3727/42/17/173001. 


\section{Figures}
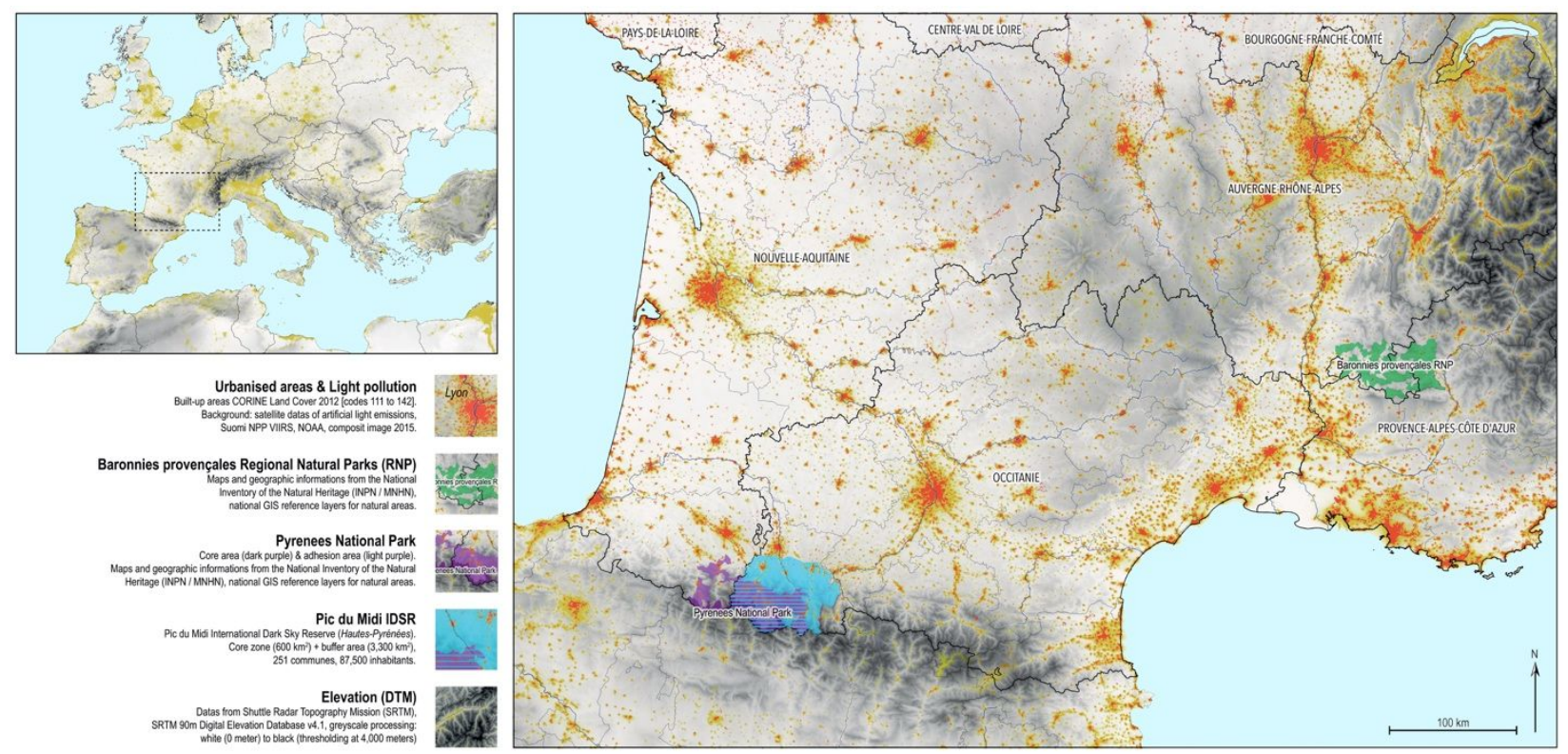

Fig. 1. Mapping of study areas. 


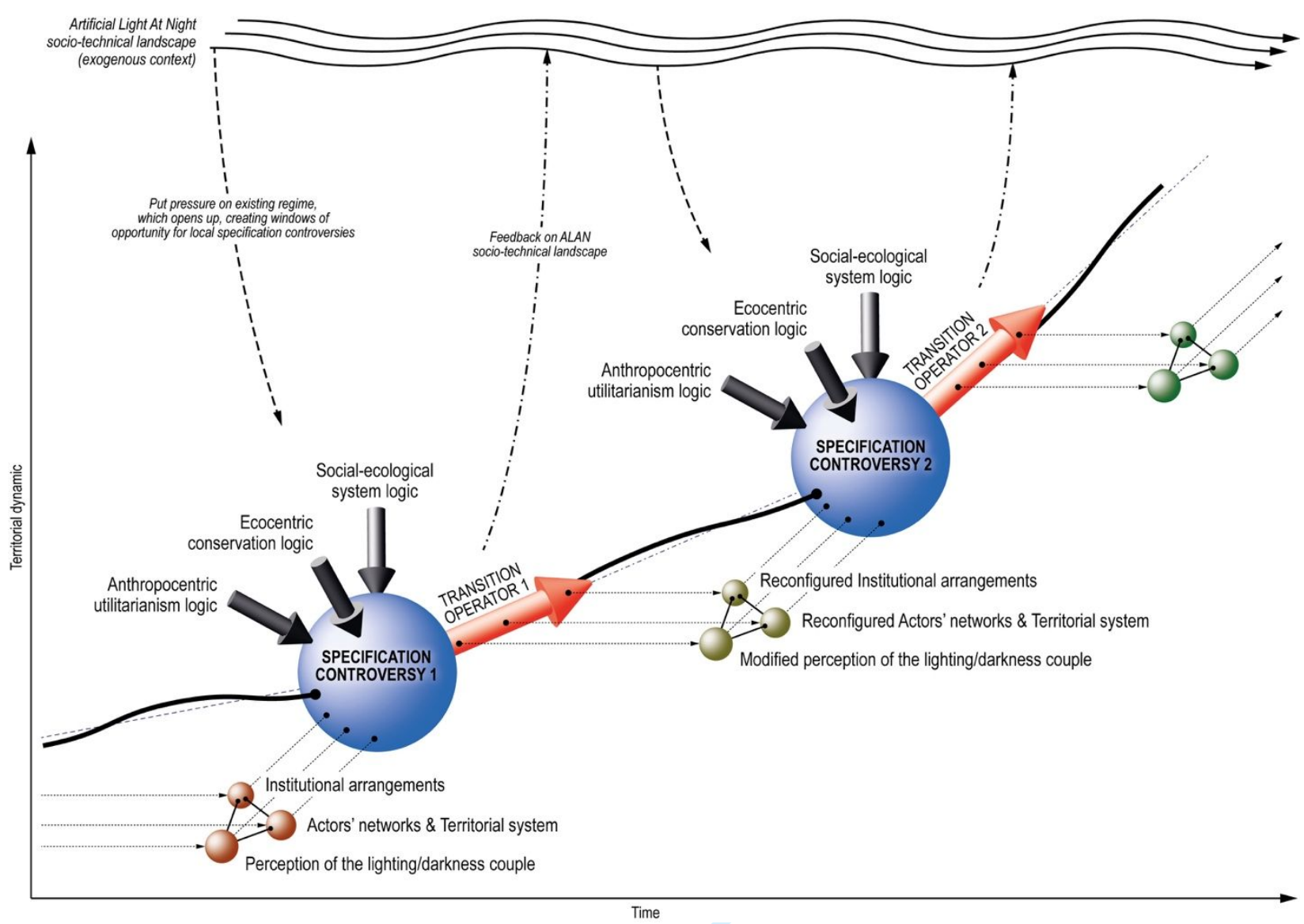

Fig. 2. Conceptual schema of bifurcations in territorial pathways under the effect of specification controversies about darkness as a resource. 